\title{
PEMBELAJARAN AGAMA DAN LINGKUNGAN DALAM KULTUR SEKOLAH ALAM: POTENSI MEMBUMIKAN KESADARAN LINGKUNGAN SEJAK DINI DI SEKOLAH
}

\author{
Abdulloh Hadziq ${ }^{1}$ \\ ${ }^{1}$ IAIN Surakarta, Jl. Pandawa Pucangan Kartosuro Sukoharjo Jawa Tengah Indonesia \\ hadziq.abdulloh@gmail.com
}

\begin{abstract}
Abstrak
Penelitian ini bertujuan untuk melakukan identifikasi tentang bagaimana konsep Integrasi Agama dan Lingkungan Alam dalam Pembelajaran Anak Usia Dini di PAUD Sekolah Alam Ungaran (SAUNG) Semarang dan dampaknya terhadap perilaku peserta didik dalam menjaga kelestarian alam. Penelitian yang dilakukan merupakan penelitian lapangan yang bersifat kualitatif. Metode pengumpulan data yang dilakukan berupa observasi, wawancara, dan dokumentasi, dengan analisis yang bersifat deskriptif. Sumber data yang dikaji meliputi penyelenggara, pengajar, peserta didik dan orang tua siswa. Selain itu, Penelitian ini menggunakan pendekatan fenomenologi yakni dengan mencari atau menemukan makna dari hal-hal yang esensial atau mendasar dari budaya di sekolah alam tersebut. Hasil dari penelitian menunjukkan bahwa sekolah tersebut mengintegrasikan pembelajarannya melalui sunnah kauniyah di alam sekitar serta kehidupan social -masyarakat yang dipadukan dengan ajaran Islam (dalil naqliyah). Sementara itu, model pembelajarannya menggunakan metode integratif dengan pendekatan Contextual Teaching and Learning. Hal tersebut didukung pula dengan desain kelas seperti halnya saung, kurikulum yang memadukan sumber ajaran Islam dengan kondisi lingkungan sekitar dan kegiatan-kegiatan yang sifatnya diluar kelas. Sehingga dapat memberi dampak signifikan bagi peserta didik dalam menumbuhkan kesadaran dan kecintaanya terhadap alam.
\end{abstract}

Kata Kunci: Alami, Kauniyah, Naqliyah, CTL

\begin{abstract}
This study attempts to identify how the concept of the integration between religion and nature environment of learning process in PAUD Sekolah Alam Ungaran (SAUNG) Semarang is, and its impact for realizing student behavior in protecting nature eternity. Applying field research as a qualitative study, researcher used observation, interviews, and documentation as the method of collecting data. Data analysis of the study is descriptive by using data from manager, teacher, student and parents. Meanwhile, this study also used phenomenology as the approach for finding the essence of school culture. This paper Founds that PAUD SAUNG Semarang integrated its learning process through sunnah kauniyah in nature and social life combined with Islamic precepts or the integration between dalil kauniyah and dalil naqliyah. On the other side, PAUD SAUNG Semarang used integrative method using Contextual Teaching and Learning (CTL) as the learning model. It also supported by unique classroom design, the curriculum (combination of Islam precepts and nature environment) and outdoor activity in learning process. So, it can improve student's awareness to love their nature
\end{abstract}

Keyword: Nature, Kauniyah, Naqliyah, CTL 


\section{PENDAHULUAN}

Saat ini masalah lingkungan kian hari semakin mengkawatirkan, sehingga mampu membuat perhatian yang luar biasa dari sebagian besar umat manusia di bumi. Hutan sebagai penyuplai oksigen makhluk hidup, semakin tidak menentu, air laut dan sungai mulai tercemar dengan zat kimia pabrik, tanah terkontaminasi dengan zat-zat berbahaya, dan masih banyak lagi yang lainnya. Hal ini, menimbulkan spekulasi makhluk hidup di bumi saat ini mengalami ancaman hidup yang serius.

Paradigma yang berkembang dalam memandang alam sebagai mesin pemberi kepuasan dan pemenuhan kebutuhan manusia adalah pemicu yang sangat berpengaruh. Cara pandang ini dipelopori oleh filosof Rene Decartes yang merupakan pembuka pemikiran mekanistik-dualistik. ${ }^{1}$ Akibatnya, pandangan terhadap alam yang dulunya bersifat organis berubah menjadi mekanis. Sehingga alam menjadi objek yang bebas dieksploitasi dan ditaklukkan demi kepentingan manusia.

Kerusakan alam bermula saat manusia memasuki sebuah era yang mereka sebut zaman modern. Manusia modern menganggap bahwa alam adalah barang yang dapat dimanfaatkan sesuka hati. ${ }^{2}$ Hal ini diperparah dengan sifat dan sikap manusia yang tamak dan serakah. Ketamakan dan keserakahan ini, mendapatkan wahana pelampiasannya dengan adanya kemajuan tekhnologi di segala bidang.

Berdasarkan UU No. 23 Tahun 1997, tentang pengelolaan lingkungan hidup. Lingkungan hidup ${ }^{3}$ adalah kesatuan ruang dengan semua benda dan

1 Bertrand Russel, Sejarah Filsafat Barat, trans. Sigit Jatmiko, dkk. (Yogjakarta : Pustaka Pelajar, 2002), 737-745.

2 Nadjamuddin Ramly, Islam Ramah Lingkungan ; Konsep Dan Strategi Islam Dalam Pengelolaan, Pemeliharaan Dan Penyelamatan Lingkungan (Jakarta : Grafindo Khazanah Ilmu, 2007), 21.

3 Lingkungan hidup sebagaimana yang dimaksud dalam undang-undang tersebut merupakan suatu sistem yang meliputi lingkungan alam hayati, lingkungan alam nonhayati, lingkungan buatan, dan lingkungan sosial. Semua komponen-komponen lingkungan hidup seperti benda, daya, keadaan, dan makhluk hidup berhimpun dalam satu wadah yang menjadi tempat berkumpulnya komponen itu disebut ruang. Pada ruang ini berlangsung ekosistem, yaitu suatu susunan organisme hidup dimana diantara lingkungan abiotik dan organisme tersebut terjalin interaksi yang harmonis dan stabil, saling memberi dan 
Hadziq, A. (2016). PEMBELAJARAN AGAMA DAN LINGKUNGAN DALAM KULTUR SEKOLAH ALAM: POTENSI MEMBUMIKAN KESADARAN LINGKUNGAN SEJAK DINI DI SEKOLAH. JURNAL TATSQIF, 14(1), 132.

kesatuan makhluk hidup termasuk di dalamnya manusia dan perilakunya yang melangsungkan perikehidupan dan kesejahteraan manusia serta makhluk hidup lainnya. Ini menjelaskan bahwa kehidupan manusia tidak bisa dipisahkan dari lingkungannya, baik lingkungan alam maupun lingkungan sosial. Semuanya akan berdampak signifikan terhadap proses kehidupan.

Ada beberapa faktor penyebab terjadinya kerusakan lingkungan hidup, diantaranya : a) kerusakan lingkungan akibat peristiwa alam, b) kerusakan lingkungan akibat perbuatan manusia, dan c) kerusakan lingkungan akibat lemahnya penegakan hukum.

Beberapa kejadian musibah yang diakibatkan menurunnya kualitas akan kesadaran terhadap lingkungan menyebabkan kita berpikir ke belakang dan menghubungkan kejadian tersebut dengan proses pendidikan selama ini. Apakah selama ini pendidikan yang mengupayakan peningkatan kepedulian masyarakat masih kurang maksimal.

Sebenarnya jauh sebelum itu, al-Qur'an dengan tegas menyatakan bahwa eksploitasi sumber daya alam $(\mathrm{SDA})^{4}$ dan lingkungan yang dilakukan generasi tempo dulu benar-benar menjadi penyebab terjadinya kerusakan lingkungan. ${ }^{5}$ Sebagaimana firman Allah SWT :

menerima kehidupan. Interaksi antara berbagai komponen tersebut ada kalanya bersifat positif dan tidak jarang pula yang bersifat negatif. Keadaan yang bersifat positif dapat terjadi apabila terjadi keadaan yang mendorong dan membantu kelancaran berlangsungnya proses kehidupan lingkungan.

4 Sumber daya alam terbagi menjadi 2 yaitu ; sumber daya alam yang bisa diperbaharui (rewenable resources) dan tidak bisa diperbaharui (irrewenable resources). Yang dimaksud SDA yang bisa diperbaharui yakni SDA yang tidak habis dipakai dan mempunyai kemampuan untuk 'mereproduksi diri' setelah dipakai manusia, misalnya ; flora, fauna, udara, dan matahari. Meskipun demikian SDA terperbaharui jika dieksploitasi secara berlebihan yakni lewat batas kemampuan untuk memulihkan diri tentu berpeluang mengakibatkan terjadinya kepunahan. Sedangkan SDA tidak bisa diperbaharui adalah SDA yang habis setelah dipakai. Dengan kata lain SDA tak terperbaharui adalah SDA yang tidak memiliki kemampuan untuk memulihkan diri sendiri setelah dipakai, misalnya ; minyak, batubara, tanah, dan sebagainya. Lihat selengkapnya ; Nadjamuddin Ramly, Islam Ramah Lingkungan ; Konsep Dan Strategi Islam Dalam Pengelolaan, Pemeliharaan Dan Penyelamatan Lingkungan (Jakarta : Grafindo Khazanah Ilmu, 2007), 21-22.

5 Mujiono Abdillah, Fikih Lingkungan : Panduan Spiritual Hidup Berwawasan Lingkungan (Yogjakarta : UPP YKPN, 2005), 8. 


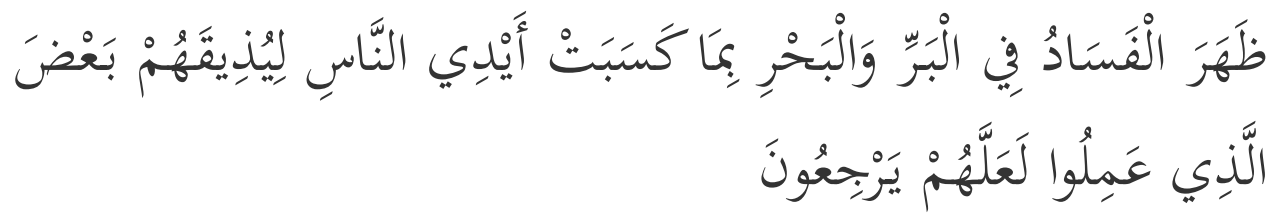

Artinya : Telah nampak kerusakan di darat dan di laut disebabkan karena perbuatan tangan manusia, supaya Allah merasakan kepada mereka sebahagian dari (akibat) perbuatan mereka, agar mereka kembali (ke jalan yang benar). (QS. al-Ruum : 41)

Semestinya kita sadar bahwa apa pesan nyata dibalik peristiwa bencana selama ini. Dari bencana tersebut seakan 'alam' bertutur memberikan 'peringatan' nyata tentang pentingnya memperlakukan alam secara bijaksana. Gugatan tersebut bukan saja ditujukan kepada pola budaya masyarakat yang memang kurang bersahabat dengan alam, namun juga terhadap variabel lainnya termasuk 'agama' dan 'pendidikan'. Agama sejauh ini dianggap sebatas penghantar seseorang shaleh secara ritual. Demikian halnya 'pendidikan', justru menciptakan jarak yang memisahkan anak dengan realitas lingkungan.

Sejarawan Amerika, Lynn White Jr., mengemukakan bahwa akar permasalahan dari krisis lingkungan sebenarnya sebagian besar religius dan pemecahannya pun menurutnya harus secara esensial dari dimensi religius juga. ${ }^{6}$ Sebagaimana yang diungkapkan juga oleh Mary Evelyn Tucker dan John Grim bahwa semangat dan nilai-nilai etika lingkungan juga bisa ditemukan dalam tradisi religius keagamaan umat manusia. ${ }^{7}$

Pendidikan sebagai sarana membentuk karakter manusia diharapkan mampu meminimalisir berbagai kemungkinan yang akan terjadi dengan alam. Terlebih keberadaan manusia sebagai unsur utama atas kerusakan alam mengharuskan pendidikan menjadi solusi atas permasalahan yang ada di masyarakat. Sehingga generasi yang akan datang menjadi bangsa yang peduli

${ }^{6}$ Lynn White Jr. dalam catatan Barbour tentang diskusi mengenai relasi ekologi dan teologi tahun1970-an. Lihat Ian G. Barbour, Menemukan Tuhan : Dalam Sains Kontemporer dan Agama trans. Fransiskus Borgias M (Jakarta : Mizan, 2005), 265-266.

${ }^{7}$ Mary Evelyn Tucker dan John Grim, dalam kata pengantar buku Islam dan Ecology, Richard C. Foltz, Frederick M. Denny and Azizan Baharuddin (ed), (USA : Harvard University Press, 2003), Xxiv-xxvii. 
akan lingkungan dengan menjaga kelestariannya.

Oleh karena itu, pendidikan lingkungan hidup harus diberikan sejak dini kepada anak-anak kita, dan yang paling penting pendidikan lingkungan hidup harus berdasarkan pengalaman langsung bersentuhan dengan lingkungan hidup sehingga pengalaman langsung tersebut dapat membentuk perilaku, nilai dan kebiasaan untuk menghargai lingkungan.

Secara rasional ada tiga alasan utama mengapa pendidikan lingkungan hidup harus diberikan sejak dini : Pertama, anak-anak harus mengembangkan rasa mencintai lingkungan hidup pada usia dini, sebab dengan pengembangan perasaan tersebut secara dini, maka perkembangan rasa itu akan tertanam dengan baik. Kedua, interaksi dengan lingkungan alam merupakan bagian penting dari perkembangan kehidupan anak yang sehat dan interaksi tersebut dapat mendorong kemampuan belajar dan kualitas hidup anak ke depan. Ketiga, memberikan pemahaman terhadap anak-anak bahwasanya dalam agama apapun dianjurkan untuk melestarikan dan melindungi alam semesta dari kerusakan.

Fenomena di atas, paling tidak menghendaki adanya upaya penyelenggaraan sistem pendidikan yang komprehensif. Karena perkembangan masyarakat dewasa ini menghendaki adanya pembinaan siswa yang dilaksanakan secara seimbang antara nilai, sikap, pengetahuan, kecerdasan, keterampilan, kemampuan komunikasi, dan kesadaran akan ekologi lingkungan. ${ }^{8}$ Tuntutan di atas, kiranya menjadi stimulus untuk mendirikan lembaga pendidikan berbasis alam.

Dalam penelitian Baiq Hadia Martanti (2009), mengenai Kajian Etika Islam Terhadap Lingkungan Hidup (Tinjauan Filosofis), dalam penelitiannya disebutkan, merupakan suatu pandangan baru bahwa Islam juga memiliki konsep dan tata cara berakhlaq terhadap lingkungan hidup. Konsep tersebut tersirat dalam Alqur'an dan Al hadits sehingga dapat dinyatakan bahwasanya Islam sangat memperhatikan lingkungan hidup, selain itu dikemukakan

8 Ridwan Nasir, Mencari Tipologi Format Pendidikan Ideal (Yogyakarta ; Pustaka Pelajar, 2005), 1. 
bahwa paradigma yang berkembang selama ini tentang alam dipengaruhi oleh antroposentrisme merupakan awal terjadinya kerusakan alam. Demikian pula artikel dari Rohinah (2014), Sekolah Alam ; Paragdigma Baru Pendidikan Islam Humanis, menjelaskan paradigma baru pendidikan Islam dalam perspektif humanisme dengan bertolak pada model sekolah alam. Model sekolah ini memiliki tiga aspek khusus, yakni: alam sebagai ruang belajar, alam sebagai media dan bahan mengajar, serta alam sebagai objek pembelajaran

Perlu diketahui, Sekolah Alam Ungaran (SAUNG) menerapkan pola pembelajaran di alam terbuka untuk melatih aspek kognitif, afektif dan psikomotorik peserta didik dengan sekolah yang membebaskan, mengeksplorasi kreatifitas dan daya fikir anak dengan metode fun learning (dimana anak merasa selalu fun tanpa merasa anak sedang belajar materi pelajaran). Dengan kekayaan dan pemandangan alam sekitar yang masih asri, dengan sumber daya pengajar yang mendukung proses pembelajaran dan dukungan fasilitas yang mencukupi, memberikan lingkungan belajar yang fresh. Suasana belajar (kelas) yang diterapkan dengan model saung, membuat anak dapat belajar sambil menikmati keindahan alam.

Melalui konsep sekolah alam itu, para peserta didik didorong untuk dekat serta berinteraksi dengan alam. Mereka dapat berinteraksi dan mengeksplorasi alam di sekitarnya. Dengan demikian, peserta didik merasa nyaman, senang, dan tidak merasa terbelenggu karena dalam hal ini pendidik/guru bukanlah satu-satunya narasumber. Di sekolah ini, pendidik ditempatkan sebagai fasilitator dan mitra.

Berdasarkan pemaparan di atas, maka yang menjadi permasalahan dalam penelitian ini adalah bagaimana konsep Integrasi Agama dan Lingkungan Alam dalam Pembelajaran Anak Usia Dini di PAUD Sekolah Alam Ungaran (SAUNG) Semarang dan dampaknya terhadap perilaku peserta didik dalam menjaga kelestarian alam. Penelitian ini menjadi penting untuk menemukan konsepsi ideal pembelajaran berbasis alam yang bernafaskan 
nilai-nilai Islam sebagai penyokongnya. Sehingga, hal tersebut dapat menjadi role model bagi implementasi pembelajaran berbasis alam bagi sekolahsekolah di Indonesia.

\section{Manusia dan Lingkungan Alam}

Kerusakan alam bermula saat manusia memasuki sebuah era yang mereka sebut dengan zaman modern. Berbekal kemampuan akal, manusia dapat menciptakan mesin-mesin yang mampu mengeruk dan mengelola kekayaan alam. Sedangkan 'manusia modern' menganggap bahwa alam adalah barang yang dapat dimanfaatkan sesuka hati, kapanpun dan dimanapun. Hal ini diperparah dengan sikap asli manusia yang tamak dan serakah. Kekayaan alam yang ada dieksploitasi hanya sekedar untuk memuaskan nafsu keserakahan, tanpa mempertimbangkan kelanjutan kehidupan dimasa yang akan datang.

Dalam Tafsir al-Misbah dijelaskan bahwasanya terjadinya kerusakan merupakan akibat dari dosa dan pelanggaran yang dilakukan oleh manusia, sehingga mengakibatkan gangguan keseimbangan di darat dan di laut. Sebaliknya, ketiadaan keseimbangan itu, mengakibatkan siksaan kepada manusia. Semakin banyak perusakan terhadap lingkungan semakin besar pula dampak buruknya terhadap manusia. Bila terjadi gangguan pada keharmonisan dan keseimbangan alam, maka kerusakan terjadi, dan ini kecil atau besar, pasti berdampak pada seluruh bagian alam, termasuk manusia, baik yang merusak maupun yang merestui kerusakan itu. ${ }^{9}$

Berdasarkan uraian di atas, kedudukan manusia sangat penting kiranya dalam menjaga keberlangsungan hidup makhluk di bumi, sehingga manusia dituntut untuk lebih aktif dalam menjaga dan melestarikan alam semesta ini.

\section{Agama dan Alam Semesta}

Dalam pembahasan yang sebelumnya telah dijelaskan, bahwasanya

${ }^{9}$ M. Quraish Shihab, Tafsir Al Misbah : Pesan, Kesan dan Keserasian Al Qur'an, volume 11 (Jakarta : Lentera Hati, 2003), 78. 
Islam memberikan konsep yang sangat jelas antara makhluk hidup (yang diciptakan) dan khaliq (sang pencipta). Keberadaan manusia di bumi, bukanlah sekedar makhluk hidup yang hidup lalu mati saja, namun lebih dari itu, ia memiliki tugas dan kewajiban sebagai makhluk bumi, yaitu sebagai khalifah Allah dan sebagai hamba Allah.

a. Selaku Khalifah Allah

Khalifah berarti pengganti, penguasa, pengelola atau pemakmur. Sebagai khalifah, manusia tidak boleh mengabaikan keserasian hidupnya berdampingan dengan alam semesta sebagai ekosistem. ${ }^{10}$ Manusia tidak dapat hidup sendirian, ia memerlukan bekal hidup yang disumbangkan oleh makhluk lain karena memang eksistensi segala makhluk itu diperuntukkan bagi kehidupan manusia, sebagaimana firman Allah SWT :

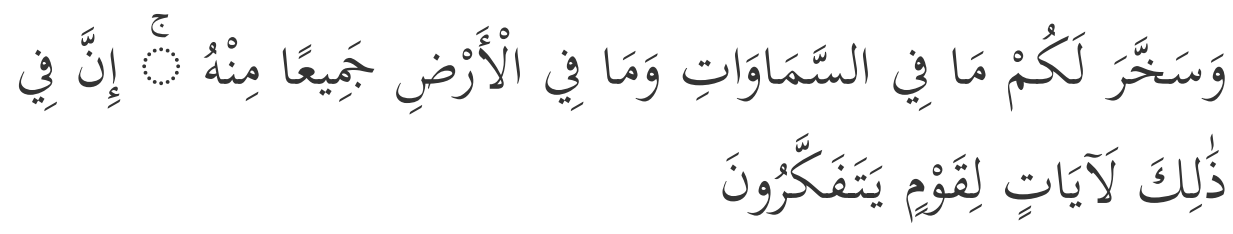

Artinya : Dan dia Telah menundukkan untukmu apa yang di langit dan apa yang di bumi semuanya, (sebagai rahmat) daripada-Nya. Sesungguhnya pada yang demikian itu benar-benar terdapat tanda-tanda (kekuasaan Allah) bagi kaum yang berfikir. (QS. al-Jaatsiyah : 13)

Menurut Imam As Shabuni, kata 'Sakhara' bermakna 'Litanfa'u Biha' yaitu agar supaya kamu mengambil manfaat darinya. ${ }^{11}$ Oleh karena itu, sebagai manusia seyogyanya kita mampu memanfaatkan dengan baik apa yang telah diciptakan Allah SWT baik di langit maupun di bumi. Sehingga kelestarian alam dapat terjaga dengan baik dan dapat bermanfaat untuk alam semesta.

Dari ungkapan al-Quran di atas, dapat dipahami bahwa salah satu syarat mutlak dalam rangka mengemban tugas sebagai khalifah

${ }^{10}$ Kaelany, Islam dan Aspek-aspek Kemasyarakatan (Jakarta : Bumi Aksara, 2000), 9.

11 Imam As Shabuni, Shafwatu at Tafasir , Juz 3 (Maktabah As Syamilah), 20. 
adalah ilmu pengetahuan. Dan ilmu pengetahuan dapat diperoleh melalui proses yang dinamakan belajar, ketika ilmu pengetahuan sudah didapatkannya maka manusia sebagai khalifah harus mampu menjalankan tugasnya, yaitu : mengelola, memanfaatkan kekayaan alam semesta ini untuk kesejahteraan dan kemakmuran manusia.

b. Selaku Hamba Allah

Beribadat kepada Allah merupakan prinsip hidup yang paling hakiki bagi ummat muslim, sehingga perilaku manusia muslim sehari-hari senantiasa mencerminkan penempatan pengabdian di atas segala-galanya. ${ }^{12}$

Menelaah lebih jauh mengenai manusia sebagai khalifah maupun manusia sebagai 'abd dalam rangka identifikasi posisi saja, posisi manusia sebagai khalifah berkuasa dan bertugas mengelola alam semesta untuk memenuhi kebutuhan manusia guna melaksanakan fungsi kehidupannya. Ini berarti manusia melaksanakan perintah Allah SWT dengan cara mengimplementasikan perintah khaliq untuk mengelola alam dengan sebaik-baiknya. Sedangkan manusia sebagai 'Abd berarti ia berkewajiban memaknai semua usaha dan kegiatannya sebagai ikhtiar dan realisasi penghambaan diri kepada Allah, termasuk melalui aktifitas mengelola alam raya dengan kekuasaan yang dimilikinya guna memenuhi kebutuhan hidup. ${ }^{13}$

Dengan demikian, dalam memanfaatkan alam semesta, manusia tidak semata-mata menggunakan rasio dalam memahami dan menghayati, tetapi ia juga harus menyertakan hati, emosi dan perasaan. ${ }^{14}$ Dengan menggabungkan rasio dengan hati, semakin banyak ilmu dan pengetahuan yang didapatkan manusia, yang bersangkutan akan

12 Kaelany, Islam Dan Aspek-Aspek Kemasyarakatan ..., 12.

${ }^{13}$ Ahmad Syar'I, Filsafat Pendidikan Islam (Jakarta : Pustaka Firdaus, 2005), 13-14 .

${ }^{14}$ Ahmad Janan Asifuddin, Mengungkit Pilar-Pilar Pendidikan Islam (Yogjakarta : UIN Sunan Kalijaga,2009), 26. 
semakin dekat kepada Sang pencipta. ${ }^{15}$ Sehingga kerusakan alam dapat diminimalisir dalam kehidupan berbangsa dan bernegara.

Untuk memanfaatkan alam agar dapat berkontribusi dalam dunia pendidikan, maka pemegang kebijakan, praktisi pendidikan ataupun masyarakat sudah sepatutnya menggunakan ide-ide kreatifnya dalam pemanfaatan lingkungan alam, sehingga alam bukan lagi sebatas pemandangan belaka bagi peserta didik, namun sudah bisa menjadi bagian dari pendidikan itu sendiri. Pendidikan dapat dijadikan sebagai upaya preventif terhadap rusaknya alam alam saat ini, dan peserta didik diharapkan dapat menjadi generasi yang mencintai lingkungan dimasa mendatang.

\section{Sekolah Alam: Integrasi Dalil Naqliyah dan Kauniyah}

Pembelajaran integratif atau terpadu menurut John Dewey adalah pendekatan untuk mengembangkan pengetahuan peserta didik dalam pembentukan pengetahuan berdasarkan pada interaksi dengan lingkungan dan pengalaman hidupnya.

Pembelajaran terpadu juga dilandasi oleh landasan normatif dan landasan praktis. Landasan normatif menghendaki pembelajaran terpadu dilaksanakan berdasarkan gambaran ideal yang ingin dicapai oleh tujuan-tujuan pembelajaran. Sedangkan landasan praktis, megharapkan pembelajaran terpadu dilaksanakan dengan memperhatikan situasi dan kondisi praktis yang berpengaruh terhadap kemungkinan pelaksanaannya untuk mencapai hasil yang optimal.

Kaitannya dengan pendidikan sadar lingkungan bagi anak usia dini, pembelajaran integrative akan memudahkan anak untuk memahami materi yang disampaikan. Dengan desain anak melihat, mengetahui, dan merasakan langsung pengalaman hidup yang dialami menunjukkan pembelajaran akan membuat anak-anak lebih 
tertarik karena sesuai dengan perkembangan kemampuan yang dimilikinya.

Sekolah alam adalah bentuk pendidikan alternatif yang menggunakan alam sebagai media utama pembelajaran murid. Di sini, anak belajar dari semua makhluk yang ada di alam semesta. Dalam konsep pendidikan sekolah alam, terdapat 3 fungsi, yakni: alam sebagai ruang belajar, alam sebagai media dan bahan mengajar, alam sebagai objek pembelajaran. ${ }^{16}$

Oleh badan dunia, PBB melalui UNESCO, pendidikan diterjemahkan menjadi beberapa tahap, pertama yaitu tahu (to know), kedua mengerti (to understand), ketiga mengerjakan yaitu mengaplikasikan (to do), dan yang paling paling terakhir adalah bagaimana bekerjasama (how to work together). ${ }^{17}$

Ini menggambarkan bahwa pendidikan selain tahu, mengerti dan dapat mengerjakannya juga bagaimana bekerjasama antar individu dengan individu lain, satu kelompok dengan kelompok lain dan seterusnya. Sehingga kemampuan untuk bekerjasama antar kelompok menjadikan pendidikan punya kaitan dengan pembangunan pendidikan untuk membentuk sumber daya manusia.

Upaya untuk melibatkan lingkungan sekitar sebagai sarana pembelajaran merupakan bagian daripada pembelajaran kontekstual (Contextual Teaching and Learning). Pendekatan kontekstual merupakan konsep belajar yang membantu pendidik mengaitkan materi yang diajarkannya dengan situasi dunia nyata anak. Anak didorong untuk menemukan hubungan antara pengetahuan yang dimilikinya dengan penerapannya dalam kehidupan mereka sebagai anggota keluarga dan masyarakat. ${ }^{18}$ Hal tersebut dilakukan dengan melibatkan komponen

16 Rohinah, Sekolah Alam ; Paragdigma Baru Pendidikan Islam Humanis, Nadwa, volume 8, no.2 (Desember, 2014), 281-294.

17 Nadjamudin Ramly, Islam Ramah ..., 75.

18 Syaiful Sagala, Konsep dan Makna Pembelajaran: Untuk Membantu Memecahkan Problematika Belajar dan Mengajar (Bandung: Alfabeta, 2010), 87. 
utama pembelajaran efektif, yakni constructivism, questioning, inquiry, learning community, modeling, reflection, dan authentic assessment. ${ }^{19}$

Pembelajaran dengan pendekatan kontekstual sendiri memiliki karakteristik sebagai berikut :

a. Pembelajaran dilaksanakan dalam konteks autentik, yaitu pembelajaran diarahkan pada ketercapaian keterampilan dalam konteks kehidupan nyata atau pembelajaran dilaksanakan dalam lingkungan yang alamiah (learning in real life setting)

b. Pembelajaran memberikan kesempatan kepada anak untuk mengerjakan tugas-tugas yang bermakna (meaningful learning)

c. Pembelajaran dilaksanakan dengan memberikan pengalaman bermakna kepada anak (learning by doing)

d. Pembelajaran dilaksanakan melalui kerja kelompok, berdiskusi, saling mengoreksi (learning in group)

e. Pembelajaran memberikan kesempatan untuk menciptakan rasa kebersamaan, bekerja sama, dan saling memahami antara satu dengan yang lain secara mendalam (learning to know each other deeply)

f. Pembelajaran dilaksanakan secara aktif, kreatif, produktif, dan mementingkan kerja sama (learning to ask, to inquiry, to work together)

g. Pembelajaran dilaksanakan dalam situasi yang menyenangkan (learning as an enjoy activity) ${ }^{20}$

Berkaitan dengan hal ini kita bisa mengkaji dari dua teori perkembangan yang anak yang relevan, antara lain Jean Piaget dan teori konstruktivis. Menurut Jean Piaget, seorang anak maju melalui empat tahap perkembangan kognitif, antara lahir dan dewasa, yaitu tahap sensorimotor, pra operasional, operasional kongkrit, dan operasional

19 Ibid.,, 88. Lihat pula Modul Pelatihan Pembelajaran Kontekstual (LAPIS), 13.

20 Masnur Muslich. KTSP Pembelajaran Berbasis Kompetensi dan Kontekstual (Jakarta: Bumi Aksara, 2011), 42. 
formal. Perkembangan sebagian bergantung pada seberapa jauh anak aktif memanipulasi dan berinteraksi aktif dengan lingkungan. Hal ini mengindikasikan bahwa lingkungan dimana anak belajar sangat menentukan proses perkembangan kognitif anak. Selanjutnya menurut Piaget bahwa anak membangun sendiri skemata-skemata dari pengalaman sendiri dengan lingkungannya. Di sini peran guru adalah sebagai fasilitator dan bukan sebagai pemberi informasi. Guru perlu menciptakan lingkungan yang kondusif bagi para siswanya.

Sementara itu, teori pembelajaran kontrutivisme merupakan teori pembelajaran kognitif yang baru dalam psikilogi pendidikan yang menyatakan bahwa siswa harus menemukan sendiri dan mentransformasikan informasi kompleks, mengecek informasi baru dengan aturan-aturan lama dan merevisinya apabila aturan-aturan itu tidak sesuai lagi. Secara teoritik menekankan peserta didik untuk dapat berperan aktif dalam menemukan ilmu baru. ${ }^{21}$ Esensi dari teori konstruktivis adalah ide bahwa harus siswa sendiri yang menemukan dan mentransformasikan sendiri suatu informasi kompleks apabila mereka menginginkan informasi itu menjadi miliknya.

Menurut prinsip konstuktivis, pendidik dalam pembelajaran berperan sebagai mediator dan fasilitator yang membantu agar proses belajar peserta didik berjalan dengan baik. fungsi mediator dan fasilitator ini dapat dijabarkan dalam beberapa tugas berikut:

a. Menyediakan pengalaman belajar yang memungkinkan peserta didik bertanggung jawab dan membuat rancangan, proses, dan penelitian. Oleh sebab itu, ceramah bukanlah tugas utama seorang pendidik.

b. Menyediakan atau memberikan kegiatan-kegiatan yang merangsang keingintahuan peserta didik dan membantu mereka untuk mengekspresikan gagasan-gagasannya dan mengkomunikasikan ide ilmiah mereka.

21 Khairuddin, et.al., Kurikulum Tingkat Satuan Pendidikan Konsep dan Implementasinya di Madrasah (Yogyakarta: Pilar Media, Cet. II, 2007), 197. 
c. Menyediakan sarana yang merangsang peserta didik berpikir secara produktif.

d. Menyediakan kesempatan dan pengalaman yang paling mendukung proses belajar peserta didik, dan guru menyemangati peserta didik.

e. Memonitor, mengevaluasi, dan menunjukkan apakah pemikiran si peserta didik jalan atau tidak. Guru juga menunjukkan dan mempertanyakan apakah pengetahuan peserta didik itu berlaku untuk menghadapi persoalan baru yang berkaitan. ${ }^{22}$

Tabel 1

Perbedaan pola pembelajaran kontekstual dan konvensional. ${ }^{23}$

\begin{tabular}{|l|l|}
\hline \multicolumn{1}{|c|}{ Konvensional } & \multicolumn{1}{c|}{ Kontekstual } \\
\hline Menyandarkan kepada hafalan & $\begin{array}{l}\text { Menyandarkan kepada memori } \\
\text { spasial }\end{array}$ \\
\hline $\begin{array}{l}\text { Pemilihan informasi } \\
\text { ditentukan oleh guru }\end{array}$ & $\begin{array}{l}\text { Pemilihan informasi berdasarkan } \\
\text { kebutuhan individu anak/siswa }\end{array}$ \\
\hline $\begin{array}{l}\text { Memberikan tumpukan } \\
\text { informasi kepada anak sampai } \\
\text { pada saatnya diperlukan }\end{array}$ & $\begin{array}{l}\text { Selalu mengaitkan informasi } \\
\text { dengan pengetahuan awal yang } \\
\text { telah dimiliki anak }\end{array}$ \\
\hline $\begin{array}{l}\text { Cenderung terfokus pada satu } \\
\text { bidang (disiplin) tertentu }\end{array}$ & $\begin{array}{l}\text { Cenderung mengintegrasikan } \\
\text { beberapa bidang }\end{array}$ \\
\hline $\begin{array}{l}\text { Penilaian hasil belajar hanya } \\
\text { melalui kegiatan akademik } \\
\text { berupa ujian/ulangan }\end{array}$ & $\begin{array}{l}\text { Menerapkan penilaian autentik } \\
\text { melalui penerapan praktis dalam } \\
\text { problem solving }\end{array}$ \\
\hline
\end{tabular}

Pada sumber tersebut, Lev Vigostsky juga meyakini bahwa pengalaman interaksi sosial merupakan hal yang penting bagi perkembangan proses berpikir anak. Aktivitas mental yang tinggi pada anak dapat terbentuk melalui interaksi dengan orang lain. Pembelajaran akan menjadi pengalaman yang bermakna bagi anak jika ia dapat

22 Paul Suparno, Filsafat Konstruksivisme dalam Pendidikan, cet. 10 (Yogyakarta: Kanisius, 1996), 65-66.

${ }^{23}$ Baharuddin dan Moh. Makin, Pendidikan Humanistik: Konsep, Teori, dan Aplikasi Praktis dalam Dunia Pendidikan (Yogyakarta: Ar-ruzz Media, 2007), 212-213. 
Hadziq, A. (2016). PEMBELAJARAN AGAMA DAN LINGKUNGAN DALAM KULTUR SEKOLAH ALAM: POTENSI MEMBUMIKAN KESADARAN LINGKUNGAN SEJAK DINI DI SEKOLAH. JURNAL TATSQIF, 14(1), 1-

melakukan sesuatu atas lingkungannya. Howard Gardner, sebagaimana dikutip dari sumber sebelumnya, menyatakan tentang kecerdasan jamak dalam perkembangan manusia yang terbagi menjadi: kecerdasan kinestetik, kecerdasan intrapersonal, kecerdasan interpersonal, kecerdasan naturalistik, kecerdasan logika matematik, kecerdasan visual spasial, kecerdasan musik. ${ }^{24}$

Dengan demikian perkembangan kemampuan berpikir manusia sangat berkaitan dengan struktur otak, sedangkan struktur otak itu sendiri dipengaruhi oleh stimulasi, kesehatan dan gizi yang diberikan oleh lingkungan sehingga peran pendidikan yang sesuai bagi anak usia dini sangat diperlukan. ${ }^{25}$ Jadi tidaklah salah jika kemudian pemerintah mendengungkan pentingnya pendidikan untuk anak sejak dini, yakni sebelum anak duduk di bangku sekolah tingkat dasar.

Agama Islam sendiri memiliki beberapa sumber hukum diantaranya al-Qur'an dan al-Hadits. Keduanya sebagai sumber ajaran Islam yang sebenarnya tidak acuh terhadap alam/lingkungan. Justru sebaliknya, sumber ini sangat berkontribusi banyak dalam implikasinya terhadap kelestarian alam.

Secara umum agama-agama samawi memiliki pandangan yang sama mengenai perlindungan terhadap alam semesta. ${ }^{26}$ Agama-agama

24 Ibid.

25 Ibid.

26 Deklarasi Assisi (1986) yang dimotori oleh World Wildlife Fund (WWF) di Assisi Italia. Para tokoh agama masing-masing diberi kebebasan menyampaikan pandangan keagamaannya terkait upaya pelestarian alam dan membangun komitmen bersama dalam deklarasi untuk menyelamatkan lingkungan alam dari krisis. Pernyataannya diantaranya ; 1. Manusia adalah pengemban amanah yang berkewajiban untuk memelihara keutuhan ciptaan-Nya, integritas bumi, serta flora dan faunanya, baik kehidupan liar maupun keadaan alam aslinya. (Pandangan Tokoh Agama Muslim), 2. Kami melawan segala terhadap segala bentuk eksploitasi yang menyebabkan kerusakan alam yang kemudian mengancam kerusakannya (Pandangan Tokoh Agama Kristiani). 3. Kita harus mendeklarasikan sikap kita untuk menghentikan kerusakan, menghidupkan kembali menghormati tradisi lama kita (Pandangan Tokoh Agama Hindu). 4. Kerusakan lingkungan hidup merupakan akibat dari ketidaktaatan, keserakahan dan ketidakpeduliaan (manusia) terhadap karunia besar kehidupan (Pandangan Tokoh Agama Budha), Rofiah Rengganis, "Mendidikan Karakter Ramah Lingkungan Bagi Anak Usia Sekolah", http://rofiahrengganis.blogspot.co.id/ diunduh pada tanggal 19 April 2016. 
samawi menyatakan bumi dan segala sesuatu yang tersimpan di dalamnya diciptakan Tuhan untuk manusia. Sebagaimana firman Allah SWT :

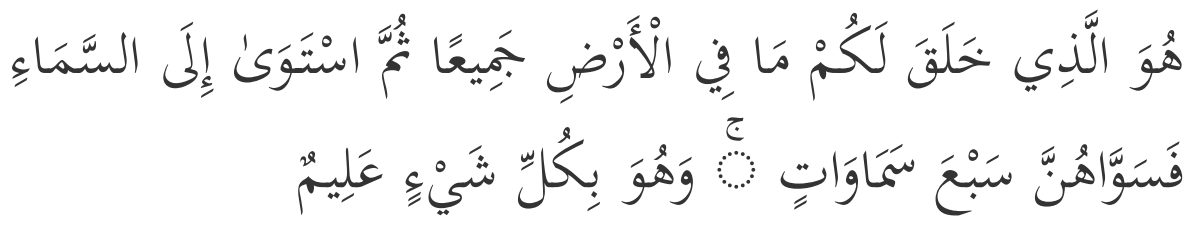

Artinya : Dia-lah Allah, yang menjadikan segala yang ada di bumi untuk kamu dan dia berkehendak (menciptakan) langit, lalu dijadikan-Nya tujuh langit dan Dia Maha mengetahui segala sesuatu. (QS. al-Baqarah : 29)

Dari ayat di atas, terdapat beberapa penjelasan mengenai alam semesta, diantaranya :

a. Penciptaan alam (segala isinya) tiada lain hanya oleh Allah SWT.

b. Tiada sesuatu yang sia-sia di bumi ini, semua memberikan manfaat bagi semua makhluk, maka manusia sebagai hamba Allah SWT seharusnya selalu menjaga hubungan baik terhadap Penciptanya dan ciptaan-Nya.

c. Seharusnya manusia menghormati lingkungan hidup guna keberlangsungan hidup manusia itu sendiri. Oleh karena itu, manusia harus mampu menanamkan rasa tanggung jawab terhadap lingkungan hidup agar kelestarian alam tetap terjaga.

Dengan demikian, dapat dilihat bahwasanya upaya untuk mengintegrasikan pendidikan, terutama pembelajaran melalui integrasi sunnah kauniyah di alam sekitar serta kehidupan sosial masyarakat. Perpaduan keduanya akan mampu menjadi jembatan kolaboratif mutualistik bagi kehidupan manusia, sehingga tujuan membentuk manusia menjadi 'khalifah' di bumi dapat terwujud dengan baik 


\section{METODE PENELITIAN}

Penelitian yang peneliti lakukan tergolong sebagai penelitian lapangan (field research) yakni penelitian yang langsung dilakukan atau pada responden. ${ }^{27}$. Oleh karena itu, obyek penelitiannya adalah berupa obyek di lapangan yang mampu memberikan informasi tentang kajian penelitian. Dalam hal ini peneliti menjadikan PAUD Sekolah Alam Ungaran (SAUNG) Semarang sebagai obyek penelitian yang difokuskan pada pelaksanaan pembelajaran di PAUD Sekolah Alam Ungaran (SAUNG) Semarang sehingga mengetahui keunggulan komperatif yang dimiliki dalam pelaksanaan pembelajaran di PAUD Sekolah Alam Ungaran (SAUNG) Semarang.

Penelitian ini termasuk dalam penelitian kualitatif, pengumpulan datanya menggunakan metode observasi, wawancara, dan dokumentasi sedangkan analisisnya bersifat deskriptif. Sumber data penelitian ini meliputi penyelenggara, pengajar, peserta didik dan orangtua (wali murid).

Selain itu, Penelitian ini menggunakan pendekatan fenomenologi yakni mencari atau menemukan makna dari hal-hal yang esensial atau mendasar dari pengalaman hidup tersebut. ${ }^{28}$ Hasil studi diharapkan dapat meningkatkan pemahaman para pembaca tentang penghayatan dan kehidupan terutama orang-orang dalam situasi khusus. Dalam hal ini manusia yang bermasalah dengan lingkungannya. Sehingga mampu memberi solusi atas permasalahan yang dihadapi pada lingkungan sekitar.

\section{HASIL DAN PEMBAHASAN}

\section{Integrasi Agama dan Lingkungan Alam di PAUD SAUNG Semarang}

Sekolah Alam Ungaran (SAUNG) Semarang lahir, dari sebuah gagasan kritis sekelompok praktisi pendidikan beserta masyarakat yang peduli akan lingkungan. Mereka berharap tercipta suatu generasi yang

27 M. Iqbal Hasan, Pokok-Pokok Materi Metode Penelitian dan Aplikasinya (Jakarta: Ghalia Indonesia, 2002), 11. 2010), 63 . 
berkualitas, sadar lingkungan dan berakhlakul karimah. Komunitas yang dipelopori oleh bapak Joko Sulistyo, Bayu Aji, Dahlan Murdani dan alm. Sholeh berinisiatif untuk membuat sebuah lembaga pendidikan yang berbasis 'alam' dan 'agama' Islam. Karena kesibukan yang dimiliki oleh para pendiri SAUNG, maka satu dari empat pelopor tersebut yakni Bapak Dahlan Murdani ditunjuk sebagai pembina sekaligus pengelola SAUNG.

Menurut Bapak Dahlan Murdani, munculnya SAUNG disebabkan karena ketidakpuasannya terhadap sistem pendidikan yang ada, dimana peserta didik hanya ditekankan pada kemampuan kognitif semata, tanpa melihat kecerdasan yang dimiliki oleh masing-masing peserta didik. Sehingga bakat dan minat peserta didik tidak mampu diakomodir oleh lembaga pendidikan yang berlangsung saat ini, lebih-lebih terkait dengan kesadaran anak untk mencintai lingkungan.

Oleh sebab itu, muncul sebuah lembaga yang disebut Sekolah Alam Ungaran (SAUNG) Semarang dengan visi menjadikan lembaga pendidikan Islam berbasis alam yang melahirkan pribadi unggul, berkarakter, dan berjiwa pemimpin.

Ada dua hal yang melandasi lahirnya SAUNG Semarang, yakni 'Agama dan Lingkungan'. Menurut para pendiri, agama memiliki peran strategis dalam membentuk kepribadian peserta didik menjadi anak yang yang berakhlakul karimah. Sehingga agama dijadikan sebagai dasar utama dalam keseluruhan.pembelajaran yang ada di Sekolah Alam Ungaran Semarang.

Sedangkan lingkungan Alam menurut pendiri SAUNG merupakan sumber belajar yang kaya di alam semesta ini. Banyak rahasia yang tersimpan dalam lingkungan yang ada disekitar kita, dan kreatifitas praktisi pendidikan disini dituntut agar lingkungan alam dapat dimanfaatkan sebagai satu kesatuan yang integral dalam kompenen pendidikan. Hanya saja lingkungan sekitar sering kali terabaikan untuk dijadikan sebagai media pembelajaran anak. 
Prinsip dasar dari berdirinya PAUD SAUNG Semarang dalam sistem pendidikannya, bahwa al Qur'an sebagai dalil naqliyah dan alam semesta beserta segala yang terjadi di dalamnya sebagai dalil kauniyah diintegrasikan dalam pembelajaran, sehingga akan tercipta manusia yang berkhlakul karimah yang sadar lingkungan.

Dari penjelasan di atas, bahwa integrasi agama dan lingkungan alam di PAUD SAUNG Semarang dapat diilustrasikan, sebagaimana gambar berikut:

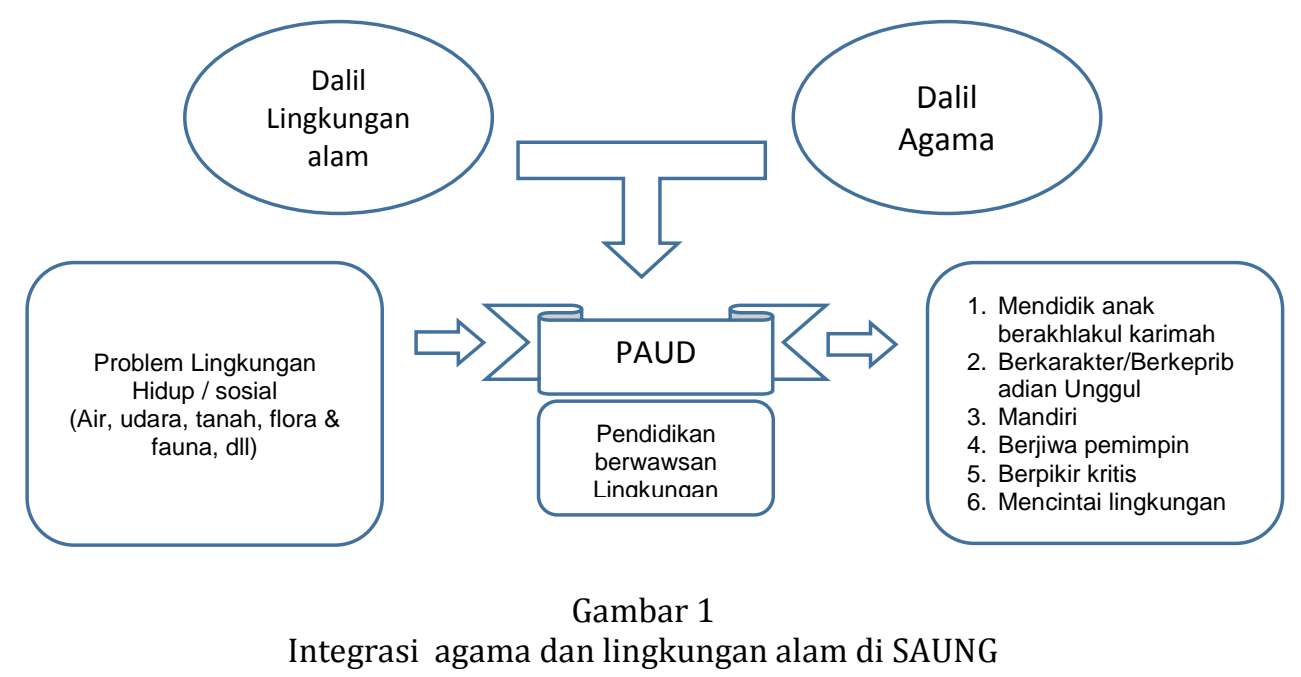

Dari gambar di atas,terlihat bahwasanya PAUD SAUNG Semarang mencoba mengintegrasikan kehidupan sosial masyarakat/sunnah kauniyah dengan ajaran agama. Dengan perpaduan tersebut sangat penting kiranya untuk membentuk manusia yang sadar lingkungan, yaitu manusia yang mampu melaksanakan tugas dan tanggung jawabnya di bumi. Sehingga kelestarian alam dapat terjaga dengan baik, dan pendidikan menjadi sebuah kebutuhan prioritas dalam kehidupan saat ini. Ada beberapa bentuk Integrasi agama dan lingkungan yang terjadi di PAUD SAUNG semarang, diantaranya : Pertama, Secara filosofis : alQur'an merupakan sumber ajaran sekaligus kebenaran Islam. Informasi tentang dunia yang nyata maupun tidak nyata, yang kemarin, sekarang 
maupun yang akan datang telah dijelaskan dalam al-Qur'an. Agama sebagai landasan teologis-normatif menjadi standar acuan yang diimplementasikan dalam pembelajaran di sekolah. Petunjuk yang ada di al-Qur'an mengenai alam semesta dijadikan referensi/sumber belajar dalam setiap kegiatan yang dilaksanakan, mulai dari mengetahui, mengenal dan memahami ciptaan-ciptaan yang ada di sekitar lingkungan sampai pada menjaga dan melestarikannya.

Kedua, Secara historis, sunnah kauniyah yang menggejala dimasyarakat dengan munculnya ketimpangan dalam kehidupan masyarakat, baik yang berhubungan dengan lingkungan hidup maupun sosial, menjadi sumber refleksi bagi masyarakat kritis. Munculnya proyek developmentalisme serta matrealisme dalam kehidupan masyarakat berakibat pada kerusakan alam. Perilaku manusia yang suka membuang sampah sembarangan, menebang pohon dengan liar, kencing di sembarang tempat, dan sebagainya mengindikasikan bahwa masyarakat tidak menyadari akibat yang akan ditimbulkan dari perilakunya sehari-hari. Oleh karenanya, PAUD SAUNG Semarang didirikan untuk membangun mentalitas masyarakat yang sadar lingkungan sejak dini.

Ketiga, Materi yakni pertimbangan utama integrasi dan penentuan dari materi pembelajarannya adalah berangkat dari Islam itu sendiri, Seperti yang dijelaskan dalam al-Quran surat al-Baqarah : 164 "Sesungguhnya dalam penciptaan langit dan bumi, silih bergantinya malam dan siang, bahtera yang berlayar di laut membawa apa yang berguna bagi manusia, dan apa yang Allah turunkan dari langit berupa air, lalu dengan air itu dia hidupkan bumi sesudah mati (kering)-nya dan dia sebarkan di bumi itu segala jenis hewan, dan pengisaran angin dan awan yang dikendalikan antara langit dan bumi; sungguh (terdapat) tanda-tanda (keesaan dan kebesaran Allah) bagi kaum yang memikirkan". 
Untuk memahami ayat itu secara tepat perlu dilakukan observasi dengan ciptaan yang ada, itulah yang dilakukan PAUD SAUNG Semarang, misalnya: peserta didik diajak untuk outing ke sawah, disana peserta didik dikenalkan tumbuh-tumbuhan, tanaman-tanaman mulai dari proses penanaman sampai pada pemanfaatan hasil dari tanaman tersebut. Selain itu peserta didik sering dikenalkan dengan hewan-hewan mulai dari mengenal bentuk sampai jenis-jenisnya dan tidak jarang peserta didik di ajak untuk susur sungai selain memperkenalkan anak mengenai sungai dan menjaga dari kebersihan/kerusakan, susur sungai dapat melatih keberanian dan saling tolong menolong karena pada saat susur sungai peserta didik dibiasakan untuk bergandengan tangan untuk menjaga satu dengan yang lainnya.

Keempat, Metode: Untuk mengimplementasikan strategi pembelajaran integrasi agama dan lingkungan alam di PAUD SAUNG Semarang dikembangkanlah beberapa pendekatan pembelajaran, yaitu; a) pendekatan pembelajaran kelas, b) pendekatan pembelajaran laboratorium, c) pendekatan pembelajaran alam (media)

Ketimpangan-ketimpangan sosial sudah tidak lagi menjadi sesuatu yang asing lagi dalam kehidupan modern. Lahirnya era industri bagi sebagian oknum menjadi kesempatan yang bagus untuk melakukan eksploitasi disemua lini.

Prilaku yang demikian, mengindikasikan kurangnya kesadaran masyarakat pada lingkungan yang tentunya berdampak negatif bagi kehidupan alam sekitar. Inilah sunnah kauniyah yang saat ini sudah menjadi budaya bangsa kita, yang tidak mau lagi kompromi dengan keberadaan lingkungan. Oleh karena itu, dengan cara pendidikan yang mendasarkan dalil kauniyah serta landasan teologis-normatif, PAUD Sekolah Alam Ungaran Semarang mencoba membentuk karakter peserta didiknya untuk sadar terhadap lingkungan. 


\section{Pembelajaran di PAUD Sekolah Alam Ungaran Semarang: Internalisasi Sadar lingkungan Sejak dini}

Era millennium sekarang ini dihadapkan pada munculnya berbagai isu lingkungan sebagai akibat adanya ketidakseimbangan ekosistem. Kepentingan antara ketersediaan sumber daya alam yang semakin terbatas dengan jumlah populasi yang menggunakan dan mengeksploitasinya. ketidakseimbangan kepentingan ini menimbulkan berbagai beban lingkungan yang akan berakibat pada kerusakan seperti : pencemaran air, pencemaran tanah, pencemaran udara, krisis energi, kerusakan hutan, kekeringan, banjir, pemanasan global dan sebagainya.

Inilah yang kemudian menjadi perhatian bersama seluruh elemen masyarakat. Gagasan mengenai 'pendidikan sadar lingkungan' dibangku sekolah merupakan sebuah alternatif yang sekarang ini menjadi nilai plus bagi pendidikan kita. Di saat, peserta didik diharapkan dapat bersikap cerdas, arif dan bertanggung jawab dalam menghadapi masalah sosial, ekonomi dan ekologi, namun yang terjadi malah sebaliknya. Contoh sederhana dari perilaku peserta didik yang kurang peduli dengan lingkungan adalah vandalisme, yang mana vandalisme itu sendiri merupakan perbuatan merusak atau menghancurkan hasil karya seni dan barang berharga lainnya (alam semesta), seperti ; mencoret-coret di dinding, memahat/menebang pohon sembarangan, dsb. Seandainya peserta didik ini sadar dengan lingkungan, maka tidak mungkin kegiatan yang sifatnya merusak atau menghancurkan dilakukannya.

Di sekolah PAUD SAUNG Semarang, proses pembelajaran mengarah pada upaya pembentukan perilaku peserta didik yang peduli terhadap lingkungan, melalui model pembelajaran yang aplikatif dan menyentuh kehidupan sehari-hari. Sementara itu, lingkungan sekolah dijadikan sebagai wahana pembiasaan perilaku peduli akan lingkungan sekitar. Dengan demikian, PAUD SAUNG Semarang dapat melaksanakan 
internalisasi atau pembiasaan perilaku peduli lingkungan dalam kehidupan sehari-hari setiap saat.

Sebagai sekolah berbasis agama yang peduli dengan alam, maka PAUD SAUNG Semarang memberikan ciri khas yang dikembangkan dalam pembelajarannya, diantaranya:

a. Desain Kelas

Kelas didesain dengan model saung dengan dinding semi terbuka yang terbuat dari kombinasi kayu hasil alam. Dengan desain kelas semi terbuka ini, anak merasa nyaman dalam mengikuti proses pembelajaran yang berlangsung. Desain saung ini, dibuat karena tidak ada batas antara peserta didik dengan alam, sehingga peserta didik terasa menyatu dengan alam itu sendiri. Selain itu, desain saung akan membuat anak tidak merasakan sebuah tekanan-tekanan yang disebabkan oleh kelas yang bertembok yang ada di sekeliling anak.

Dengan demikian, desain kelas saung membantu model pembelajaran kontekstual, dimana desain kelas saung akan memberikan perhatian kemungkinan anak berinteraksi langsung dengan alam dalam melakukan proses pembelajaran.

b. Materi pembelajaran

Dikarenakan PAUD SAUNG Semarang merupakan sekolah dengan berlandaskan agama yang peduli dengan lingkungan, maka materi yang digunakan merupakan kombinasi dari kurikulum dari DEPDIKNAS dan kurikulum sekolah yang notabene mengembangkan pelajaran agama Islam, termasuk baca al Qur'an, do'a-do'a, akhlaq, Qur'an-Hadist, Fasholatan, dan sebagainya.

PAUD SAUNG Semarang bertujuan agar peserta didik nantinya menjadi generasi Islam yang kuat, kritis, dan berakhlaq mulia. Ini tidak lepas dari doktrin agama yang dilakukan oleh PAUD SAUNG itu sendiri, yang kita tahu sebagai sekolah yang berbasiskan Islam. 
c. Sumber belajar

Lingkungan yang ada disekitar PAUD SAUNG dijadikan sebagai sumber belajar bagi anak-anak dalam proses pembelajaran, seperti : Sawah, hutan, kebun, sungai, kolam, dan sebagainya. Lingkungan tersebut akan membantu anak untuk dapat lebih memahami materi yang disampaikan. Sehingga anak akan merasakan pengalaman belajar yang langsung dapat diketahui, diamati, dan disimpulkan.

d. Laboratorium alam

Laboratorium alam merupakan upaya pihak lembaga untuk memanfaatkan lingkungan alam sekitar sebagai bagian dari proses belajar mengajar peserta didik. Pemanfaatan alam akan membantu anak dalam penerjemahan materi yang biasanya disampaikan hanya lewat buku / kata saja. Dengan memanfaatan alam juga, anak mampu untuk mengatasi secara langsung kejadian atau pengalaman yang ada disekitarnya, dan tentunya ini akan lebih menyenangkan bagi anak-anak.

Dalam pelaksanaan pembelajaran di PAUD SAUNG Semarang, didukung dengan kegiatan-kegiatan sebagai berikut : Berkebun, outbond, Outing (kunjungan keluar), pentas seni, berenang, eksperimen ilmiah, wudlu sebelum belajar, shalat dhuha, cuci tangan sebelum makan, gosok gigi, masak, baca/hafalan surat-surat pendek, do'a, market day, dan sebagainya. Kegiatan-kegiatan tersebut dilakukan sesuai dengan jadwal yang ditentukan oleh pihak sekolah dan disesuaikan dengan tema yang dipelajarinya pada saat itu. Sehingga anak dalam proses belajar mengajar tidak sekedar diberikan kebebasan yang penuh akan tetapi didampingi dan kemudian diarahkan oleh pendidik.

Selain itu kurikulum pembelajarannya menggunakan model spider web, yakni ; Setelah ditentukan tema, kemudian dibahas dengan mengacu pada standar kompetensi yang sudah ditentukan 
oleh pendidik agar dapat dikuasai peserta didik. Karena kurikulum adalah diintegrasikan dengan DEPDIKNAS maka tema yang diangkat adalah bentuk kolaborasi antara kurikulum dari DIKNAS dan dari pihak sekolah, seperti : alat komunikasi, Hutan, sawah, Kebun binatang, dsb.

Pendidik di PAUD SAUNG Semarang, bukan lagi sebagai instruktur, namun lebih berperan sebagai fasilitator, pembimbing dan motivator dengan menciptakan suasana anak menjadi kreatif, menyenangkan dan fokus pembelajaran pada kegiatan peserta didik. Pembelajaran model integratif di PAUD SAUNG Semarang melakukan pendekatan melalui contextual teaching and learning (CTL) dalam mendesain model pembelajarannya. Kontektualisasi dipahami sebagai upaya untuk menghubungkan dengan konteks yang bersangkutan langsung. Dengan demikian dapat dipahami, bahwa pendekatan kontekstual bermaksud melakukan sebuah proses dimana peserta didik dihadapkan secara langsung dengan materi yang sedang dipelajarinya, serta peserta didik mampu menghubungkan teori yang ada dengan fakta di lapangan/konkrit.

Ada beberapa hal yang dapat dilihat sebagai bentuk dari pendekatan kontektual yang ada dalam proses belajar mengajar di PAUD SAUNG Semarang, diantaranya:

e. Mendidik peserta didik untuk mandiri

Di SAUNG Semarang peserta didik dilatih untuk berfikir kritis, menganalisa situasi dan kondisi sekitar dengan sendirinya, dan peserta didik mampu untuk bersikap mandiri. Misalnya : mencuci piring sendiri setelah makan, market day, dan lain sebagainya.

f. Pembelajaran berbasis problem

Peserta didik dalam memahami setiap materi yang diberikan dari pendidik, berangkat dari situasi dimana materi tersebut dari permasalahan bersama yang ada di lingkungan sekitar, untuk 
kemudian dipecahkan secara bersama-sama. Seperti halnya pemberian tugas kepada peserta didik untuk mengamati hewan tertentu yang kemudian nanti dapat dipresentasikan dihadapan kelas.

g. Menghormati keberagaman peserta didik

Keberadaan peserta didik berasal dari berbeda-beda suku, jenis, golongan dan masyarakat, dan tentunya diperlukan sebuah perhatian dari pendidik agar tidak ada lagi kesenjangan dalam proses belajar mengajar. Peserta didik mampu bersikap toleran, saling menghormati satu sama lain.

h. Belajar kooperatif/kolaboratif

Dikarenakan kemampuan peserta didik berbeda antara satu dengan yang lainnya, Belajar kolaboratif ini dilakukan saat ada satu dari sekian banyak yang ada memiliki kemampuan yang lebih. Oleh karena itu, anak tersebut harus bisa menjadi fasilitator bagi anakanak yang lain agar dapat mengetahui informasi/pengalaman baru.

Dilihat dari beberapa hal di atas, dapat disimpulkan bahwa model pembelajaran di PAUD SAUNG Semarang menggunakan model pembelajaran integratif dengan system tematik, khususnya terkait dengan lingkungan yang kemudian di lakukan secara kontekstual.

\section{Efektifitas pendidikan berbasis lingkungan di PAUD Sekolah Alam} Ungaran Semarang terhadap perilaku peserta didik dalam menjaga kelestarian alam

PAUD SAUNG Semarang dalam melaksanakan pembelajarannya, dilihat dari kurikulum sebenarnya tidak jauh berbeda dengan sekolah formal pada umumnya, hanya saja media pembelajarannya yang terkesan menjadikan PAUD SAUNG Semarang memiliki nilai plus, dibandingkan dengan sekolah lain, berikut beberapa hal yang dapat dilihat sebagai dampak positif dari pembelajaran yang dilakukan di PAUD SAUNG Semarang, diantaranya : 
a. Mendidik anak berakhlakul karimah.

PAUD SAUNG Semarang merupakan salah satu lembaga pendidikan yang komitmen dan konsisten dalam upaya menciptakan generasi yang berakhlakul karimah, ini dilihat dari upaya lembaga yang mencoba mengintegrasikan agama dan lingkungan alam. Karena PAUD SAUNG Semarang merupakan sekolah yang berbasis Islam, maka dalam pembelajarannya anak-anak sering dilatih melakukan kegiatan-kegiatan Islami misalnya berwudlu sebelum belajar, melaksanakan shalat dhuha, membaca do'a sebelum belajar, tolongmenolong sesama teman, saling menghormati, dan sebagainya. Kegiatannya dilakukan secara kontinyu dengan harapan peserta didik akan terbiasa melakukannya dimanapun dan kapanpun ia berada.

b. Memiliki penguasaan ilmu pengetahuan.

Meskipun peserta didik belajar di alam, namun dalam kegiatannya anak-anak juga sudah dikenalkan dengan tekhnologi sekarang ini, misalnya : dalam pembelajaran di indoor/di saung anak-anak seringkali diajak nonton film/dongeng menggunakan laptop, dsb. Dan juga ketika melakukan eksperimen ilmiah, anak-anak diberikan kesempatan untuk mengetahui, memahami serta menyimpulkan pemahaman tentang apa yang dia lakukan. Hal ini membuat pengetahuan dan kemampuan anak lebih kritis.

c. Menjadikan pemimpin yang berkarakter berani, kuat dan bertanggung jawab.

Satu hal yang tidak dapat dilewatkan dari pembelajaran di PAUD SAUNG Semarang, yaitu : komitmen pada upaya penciptaan pemimpin yang berkarakter kuat, berani dan bertanggung jawab. Lebih jelasnya, anak-anak di sekolah alam dilatih untuk menjadi peserta didik yang pembeo. Mereka diarahkan menjadi generasi yang kreatif \& inovatif dan berjiwa pemimpin. Dalam pemahaman pemimpin disini, bukan sekedar memimpin untuk sebuah komunitas 
social saja, akan tetapi lebih dari itu, diharapkan peserta didik dapat memimpin untuk dirinya sendiri, yakni bertanggung jawab, toleran, dan sebagainya. Sifat dan sikap seorang pemimpin dalam pembelajarannnya di PAUD SAUNG Semarang biasanya dilakukan pada saat outbond, outing, dll.

d. Mencetak generasi yang mandiri

Setiap manusia pasti menginginkan menjadi pembelajar aktif sepanjang hayat, sehingga pendidikan menjadi sebuah alternative untuk menanamkan sifat-sifat kemandirian tersebut. Di PAUD SAUNG Semarang, pada prinsipnya sudah dilatih dan dikenalkan kepada peserta didik, ini terlihat saat pemberian tugas kepada anak-anak saat outing ke kebun binatang. Anak-anak diminta melakukan laporan dengan hasil yang diamati selama penelitian dan nanti coba dibandingkan dengan hasil temannya. Walaupun terkesan sederhana ini akan melatih anak untuk bersikap mandiri dan bertanggung jawab. Belum lagi latihan seperti menggosok gigi dengan sendiri, selalu dibiasakan saat anak berada di sekolah dan juga market day. Sehingga anak-anak terbiasa dan mampu dikemudian hari untuk melakukan aktifitas dengan sendiri.

e. Menumbuhkan perilaku anak cinta lingkungan

Seringnya pembelajaran yang dilakukan di PAUD Semarang, dengan segala kegiatan/aktifitas yang dilakukannya berdampak positif bagi kepribadian anak dalam mencintai lingkungannya. Seperti halnya, berkebun. Dengan berkebun anak-anak dilatih dan dibiasakan untuk melestarikan tanaman yang ada disekitar kita sehingga tidak ada lagi kejadian penebangan hutan secara liar dan sembarangan. Membuang sampah pada tempatnya, memelihara binatang, dll. akan membuat anak peduli akan lingkungan yang ada di sekitarnya.

Banyak kasus menunjukkan, keberadaan PAUD SAUNG Semarang dirasa cocok untuk usia anak-anak. Sebab interaksi yang dilakukan di 
PAUD SAUNG Semarang dalam pembelajarannya memang menyenangkan. Wajar saat peserta didik merasa nyaman dan senang. Pendekatan pembelajaran yang memprioritaskan interaksi yang sehat diantara peserta didik, pendidik atau fasilitator, dan orang tua menjadikan situasi belajar bagaikan pertemanan. Namun lebih dari itu, esensi dari pembelajarannya adalah memahami alam raya yang ada di sekitar kita.

Efektifitas dari pembelajaran di PAUD SAUNG Semarang itu sendiri, bisa dikatakan efektif sebab dalam pembelajarannya PAUD SAUNG Semarang sebagaimana yang telah kita ketahui, di SAUNG memanfaatkan lingkungan alam sebagai sumber belajar bagi anak. Alam semesta beserta isinya dapat menjadikan proses pembelajaran lebih menarik bagi anak. Hal ini tidak lepas dari : Pertama, Desain kelas seperti halnya saung memberikan inspirasi bahwasanya tidak ada tekanan atau beban dalam belajar, suasana yang sejuk dan sehat dengan pohon rindangnya mampu membuat anak lebih semangat dalam proses belajar. Kedua kurikulum yang memadukan sumber ajaran Islam dengan kondisi lingkungan sekitar mampu memberikan motivasi tersendiri untuk bertindak sesuai dengan ajaran agama dengan baik. Ketiga, kegiatan-kegiatan yang sifatnya diluar kelas misalnya, Out bond, outing, berkebun dan sebagainya dapat membuat anak berkepribadian kuat, khususnya dalam hal menjaga dan melestarikan lingkungan.

Konsep dari PAUD SAUNG Semarang paling tidak harus diberikan apresiasi oleh semua pihak. Keberanian untuk melakukan sebuah alternative dan teroboson dalam upaya mencetak generasi yang sadar lingkungan harus dikasih acungan jempol. Dengan konsep sekolah alam, orang tua dan masyarakat memiliki sebuah 'harapan baru' menuju peradaban yang positif. 


\section{PENUTUP}

PAUD Sekolah Alam Ungaran (SAUNG) Semarang, mencoba mengintegrasikan pembelajaran melalui integrasi sunnah kauniyah di alam sekitar serta kehidupan sosial-masyarakat yang dipadukan dengan ajaran Islam, atau integrasi dalil kauniyah dengan dalil naqliyah. Perpaduan kedua variable tersebut dalam sistem pendidikan dipandang penting mengingat dengan keduanyalah proses pembentukan manusia menjadi khalifah di bumi dapat terwujud. Selain itu, model pembelajaran di PAUD SAUNG Semarang menggunakan metode integratif dengan pendekatan Contekstual Teaching and Learning (CTL). Dan agenda utama dari PAUD SAUNG Semarang adalah membangun sebuah peradaban generasi yang mampu menyelaraskan nilainilai dan ajaran agama sebagai solusi atas permasalahan lingkungan.

Efektifitas dari pembelajaran di PAUD SAUNG Semarang itu sendiri, bisa dikatakan efektif sebab dalam pembelajarannya PAUD SAUNG Semarang sebagaimana yang telah kita ketahui, di SAUNG memanfaatkan lingkungan alam sebagai sumber belajar bagi anak. Alam semesta beserta isinya dapat menjadikan proses pembelajaran lebih menarik bagi anak. Hal ini tidak lepas dari : Pertama, Desain kelas seperti halnya saung memberikan inspirasi bahwasanya tidak ada tekanan atau beban dalam belajar, suasana yang sejuk dan sehat dengan pohon rindangnya mampu membuat anak lebih semangat dalam proses belajar. Kedua kurikulum yang memadukan sumber ajaran Islam dengan kondisi lingkungan sekitar mampu memberikan motivasi tersendiri untuk bertindak sesuai dengan ajaran agama dengan baik. Ketiga, kegiatan-kegiatan yang sifatnya diluar kelas misalnya, Out bond, outing, berkebun dan sebagainya dapat membuat anak berkepribadian kuat, khususnya dalam hal menjaga dan melestarikan lingkungan. 


\section{DAFTAR PUSTAKA}

As Shabuni, Imam. Shafwatu at Tafasir , Juz. 3. Maktabah As Syamilah.

Asifuddin, Ahmad Janan. 2009. Mengungkit Pilar-Pilar Pendidikan Islam.

Yogjakarta: UIN Sunan Kalijaga.

Baharuddin dan Moh. Makin. 2007. Pendidikan Humanistik: Konsep, Teori, dan

Aplikasi Praktis dalam Dunia Pendidikan. Yogyakarta: Ar-ruzz Media.

Barbour, Ian G. 2005. Menemukan Tuhan : Dalam Sains Kontemporer dan

Agama trans. Fransiskus Borgias M. Jakarta : Mizan.

Hasan, M. Iqbal. 2002. Pokok-Pokok Materi Metode Penelitian dan Aplikasinya. Jakarta: Ghalia Indonesia.

Khairuddin, et.al., 2007. Kurikulum Tingkat Satuan Pendidikan Konsep dan Implementasinya di Madrasah, cet. II. Yogyakarta: Pilar Media.

Mary Evelyn Tucker dan John Grim, dalam kata pengantar buku Islam dan

Ecology, Richard C. Foltz, Frederick M. Denny and Azizan Baharuddin (ed), (USA : Harvard University Press, 2003)

Mujiono Abdillah, Fikih Lingkungan : Panduan Spiritual Hidup Berwawasan Lingkungan (Yogjakarta : UPP YKPN, 2005)

Muslich, Masnur. 2011. KTSP Pembelajaran Berbasis Kompetensi dan Kontekstual. Jakarta: Bumi Aksara.

Nasir, Ridwan. 2005. Mencari Tipologi Format Pendidikan Ideal. Yogyakarta ; Pustaka Pelajar.

Nur, Mohamad. 1998. Teori-teori Perkembangan. Surabaya: Institut Keguruan dan Ilmu Pendidikan Surabaya, Depdikbud Direktorat Pendidikan Tinggi.

Ramly, Nadjamuddin. 2007. Islam Ramah Lingkungan ; Konsep Dan Strategi Islam Dalam Pengelolaan, Pemeliharaan Dan Penyelamatan Lingkungan. Jakarta : Grafindo Khazanah Ilmu.

Rohinah. 2014. "Sekolah Alam ; Paragdigma Baru Pendidikan Islam Humanis", Jurnal Nadwa. volume 8, No. 2 (Desember), 281-294. 
Russel, Bertrand. 2002. Sejarah Filsafat Barat, trans. Sigit Jatmiko, dkk. Yogjakarta : Pustaka Pelajar.

Sagala, Syaiful. 2010. Konsep dan Makna Pembelajaran: Untuk Membantu Memecahkan Problematika Belajar dan Mengajar. Bandung: Alfabeta.

Shihab, M. Quraish. Tafsir Al Misbah : Pesan, Kesan dan Keserasian Al Qur'an, volume 11. Jakarta : Lentera Hati.

Suparno, Paul. 1996. Filsafat Konstruksivisme dalam Pendidikan, cet. 10. Yogyakarta: Kanisius.

Syaodih, Nana. 2010. Metode Penelitian Pendidikan. Bandung : Remaja Rosdakarya.

Syar'i, Ahmad. Filsafat Pendidikan Islam. Jakarta : Pustaka Firdaus. 